\title{
Upland Rice Yield as Affected by Previous Summer Crop Rotation (SOYbean OR UPLAND Rice) AND GLYPHOSATE MaNAGEMENT ON COVER CROPS ${ }^{1}$
}

\author{
Produtividade do Arroz de Terras Altas Afetada pela Rotação de Cultura e pelo Manejo de \\ Glifosato nas Plantas de Cobertura do Solo
}

NASCENTE, A.S. ${ }^{2}$, CRUSCIOL, C.A.C. ${ }^{3}$, STONE, L.F. ${ }^{3}$, and COBUCCI, T. ${ }^{3}$

\begin{abstract}
The appropriate chemical management of cover crops in no-tillage aims to obtain greater benefits with its employment in agricultural systems. The objective of this study was to assess upland rice yield as affected by the previous summer crop, species and desiccation timing of cover crops by glyphosate. Sown cover crops were sown (November 2007), followed by rice in half of the experimental area and soybean in the other half (November 2008). After the harvesting of these crops, the same cover crops were sown again (March 2009) and followed by upland rice in the total area (November 2009). The experiment consisted of the combination of five cover crops (fallow, Panicum maximum, Brachiaria ruziziensis, $B$. brizantha and Pennisetum glaucum), four desiccation timings (30,20, 10 and 0 days before rice sowing), and two antecedents of the summer crop (rice or soybean) under no-tillage system (NTS), plus two control treatments at conventional tillage system (CTS). Cover crops significantly affect rice grain yield and its components. There is a significant tendency to highest yield when cover crop desiccation is conducted farther from the rice sowing date (from 2,577.1 kg ha-1 - desiccation at rice sowing to $3,115.30 \mathrm{~kg} \mathrm{ha}^{-1}$ - desiccation 30 days before rice sowing). Soybean as an antecedent of summer crop allows better upland rice yield $\left(3,754 \mathrm{~kg} \mathrm{ha}^{-1}\right)$ than rice as an antecedent of summer crop $\left(2,635 \mathrm{~kg} \mathrm{ha}^{-1}\right)$; fallow/soybean/fallow (4,507 kg ha-1) and millet/soybean/millet $\left(4,765 \mathrm{~kg} \mathrm{ha}^{-1}\right)$ rotation at no-tillage system, and incorporated fallow / soybean/ incorporated fallow $\left(4,427 \mathrm{~kg} \mathrm{ha}^{-1}\right)$ at conventional tillage system allow the highest rice yield; upland rice yield is similar at no-till $\left(3,194 \mathrm{~kg} \mathrm{ha}^{-1}\right)$ and till system $\left(2,878 \mathrm{~kg} \mathrm{ha}^{-1}\right)$.
\end{abstract}

Keywords: Oryza sativa, Brachiaria brizantha, Brachiaria ruziziensis, Panicum maximum, Pennisetum glaucum, soil management, crop-livestock integration.

\begin{abstract}
RESUMO - O correto manejo quimico das plantas de cobertura visa obter maiores beneficios com a sua introdução nos sistemas agrícolas. O objetivo deste estudo foi avaliar como a produção do arroz de terras altas é afetada pela safra de verão anterior, pela espécie e pela época de dessecação das plantas de cobertura por glifosato. Foram semeadas plantas de cobertura (novembro de 2007), seguidas pelo arroz em metade da área experimental e soja na outra metade (novembro de 2008); após a colheita dessas culturas, as mesmas plantas de cobertura foram semeadas novamente (março de 2009), seguidas pela semeadura do arroz de terras altas (novembro de 2009) em toda a área experimental. Assim, o experimento consistiu na combinação de cinco plantas de cobertura (pousio, Panicum maximum, Brachiaria ruziziensis, B. brizantha e Pennisetum glaucum) $x$ quatro épocas de dessecação (30, 20, 10 e 0 dias antes da semeadura do arroz) e dois antecedentes da safra de verão (arroz ou soja) no sistema plantio direto (SPD), mais dois tratamentos controle no sistema convencional (SC). As culturas de cobertura alteram significativamente a produtividade de grãos do arroz de terras altas e seus componentes. Há tendência significativa de se obter maior
\end{abstract}

Recebido para publicação em 27.6.2012 e aprovado em 19.10.2012.

2 Universidade Estadual Paulista - UNESP, Faculdade de Ciências Agronômicas, Dep. de Agricultura, Fazenda Experimental Lageado, Caixa Postal 237, 18610-307 Botucatu-SP, <crusciol@fca.unesp.br>; ${ }^{3}$ Embrapa Arroz e Feijão, Rodovia GO-462, Km 12, Zona Rural, Caixa Postal 179, 75375-000 Santo Antônio de Goiás-GO, <adriano@cnpaf.embrapa.br>, <stone@cnpaf.embrapa.br>, <cobucci@cnpaf.embrapa.br>. 
produtividade do arroz quando a dessecação das culturas de cobertura é feita mais distante da época de semeadura de arroz (de 2.577,1 $\mathrm{kg} \mathrm{ha}^{-1}$, dessecação realizada no dia da semeadura, para $3.115,3 \mathrm{~kg} \mathrm{ha-1}$, dessecação realizada 30 dias antes da semeadura do arroz). Soja como safra de verão anterior permite maior produção de arroz de terras altas (3.754 $\mathrm{kg} \mathrm{ha}^{-1}$ ) do que arroz como antecedente de safra de verão (2.635 $\left.\mathrm{kg} \mathrm{ha}^{-1}\right)$. Rotação pousio/soja/ pousio (4,507 $\mathrm{kg} \mathrm{ha}^{-1}$ ) e milheto/ soja/milheto $\left(4,765 \mathrm{~kg} \mathrm{ha}^{-1}\right)$ no plantio direto e pousio incorporado/soja/pousio incorporado $\left(4,427 \mathrm{~kg} \mathrm{ha}^{-1}\right)$ no sistema de plantio convencional permitiram maior produção de arroz; a produtividade do arroz é semelhante em plantio direto $\left(3,194 \mathrm{~kg} \mathrm{ha}^{-1}\right)$ e em plantio convencional $\left(2,878 \mathrm{~kg} \mathrm{ha}^{-1}\right)$.

Palavras-chave: Oryza sativa, Brachiaria brizantha, Brachiaria ruziziensis, Panicum maximum, Penissetum glaucum, manejo do solo, integração lavoura-pecuária.

\section{INTRODUCTION}

Nowadays, sustainable agriculture consists of many practices that entail the idea of an agricultural system instead of thinking only of one crop and one year (Dabney et al., 2001). This diversification of agricultural activities aims to increase the ecological, economical and social development of agriculture (Filizadeh et al., 2007; Crusciol et al., 2010). Accordingly, the increased diversity of plant species in an environment brings benefits such as better exploitation of resources, reduced damage caused by pests and lower incidence of pathogens, greater weed control, increased crop yield, and greater adequate stability of production (Yahuza, 2011). Therefore, crop rotation, cover crops, no-tillage system (NTS) are examples of essential practices in sustainable agricultural systems (Mahmoudi et al., 2011).

In Brazil about 50 million hectares of land area is being cultivated with annual crops and about half of this area is under NTS (Conab, 2011). Under such farming system, the inclusion of cover crops before the sowing of crops is an essential requirement (Crusciol et al., 2010). Thus, forage species like Brachiaria and Panicum have stood out, because they produce a large amount of straw and remain for a longer period on the soil surface due to their high $\mathrm{C}: \mathrm{N}$ ratio (Crusciol et al., 2010; Pacheco et al., 2011).

According to Timossi et al. (2007) and Constantin et al. (2008), higher dry matter accumulation of cover crop cause more nutrient cycling. Cover crops can increase the nutrient use efficiency of farming systems, because they can tap nutrients from deeper layer to soil surface, which occurs due to the decomposition and mineralization of their residues (Crusciol et al., 2010). In addition, they could reduce the loss of nutrients such a nitrogen in eroded soil (Dabney et al., 2001). Meanwhile, Souza et al. (2006) and Yahuza (2011) suggest that cover crops may have both positive (cycling of nutrients, weed suppression, and erosion control) and negative ( $\mathrm{N}$ deficiency on crop residues with high C:N ratio or allelopathic effects) impacts on the development of plants.

Therefore, to achieve greater effectiveness from a cover crop, it is essential to assess their performance in different cropping system. In addition, the suitable pre-emergence herbicide application timing on these cover crops is another strategy to reach higher crop yield (Silva et al., 2006; Constantin et al., 2008, 2009; Nunes et al., 2009; Nascente et al., 2012).

The chemical management of cover crops, before the sowing of sequential crops, is normally conducted by applying glyphosate (Nascente \& Crusciol, 2012; Nascente et al., 2012). However, glyphosate is characteristically a systemic herbicide, and it will take a few days to entirely kill cover crops (Constantin et al., 2009). Thus, when glyphosate is applied close to the following crop sowing day, cover crops are still alive and standing (Constantin et al., 2008). Green grasses are not easily cut using a planter machine and thereby reduce the efficiency of the sowing operation (Grego \& Benez, 2003). Additionally, they can create initial shading on the emerging rice seedlings, thereby damaging their development (Constantin et al., 2009; Nascente et al., 2012). Furthermore, there is the possibility of root exudation of glyphosate 
from cover crops to rice (Coupland \& Lutman, 1982).

Moreover, upland rice crop is not having good results under NTS yet (Nascente et al., 2011). Therefore, it is important to develop technologies to have better rice performance under NTS. According to Dabney et al. (2001), the identification of cover crop species, determining the time of their sowing, and killing are strategies for a successful NTS performance and will provide improved crop yield. The objective of this study was to assess upland rice yield as affected by previous summer crop (upland rice or soybean), species and desiccation timing of cover crops, and tillage system (conventional tillage or notillage).

\section{MATERIAL AND METHODS}

A field experiment was conducted in Santo Antônio de Goiás, GO, Brazil (16 $27^{\circ}$ latitude, $49^{\circ} 17^{\prime}$ longitude and $823 \mathrm{~m}$ altitude). Regional climate is tropical savanna, classified as an Aw according to the Köppen classification. There are two well defined seasons, normally dry from May to September and rainy from October to April; annual mean rainfall is $1.500 \mathrm{~mm}$. Local annual mean temperature is $22.7^{\circ} \mathrm{C}$, annually ranging from $14.2^{\circ} \mathrm{C}$ to $34.8^{\circ} \mathrm{C}$.

The soil was an Oxisol in slight undulating topography (Embrapa, 2006). The textural values were clay $540 \mathrm{~g} \mathrm{~kg}^{-1}$, silt $110 \mathrm{~g} \mathrm{~kg}^{-1}$ and sand $350 \mathrm{~g} \mathrm{~kg}^{-1}$. For soil chemical characterization 48 soil samples were collected from each of the following layers $0-5 \mathrm{~cm}, 5-10 \mathrm{~cm}$ and $10-20 \mathrm{~cm}$ depth before the experiment (Table 1 ). $\mathrm{P}$ and $\mathrm{K}$ were extracted by Mehlich 1 extracting solution $\left(0.05 \mathrm{M} \mathrm{HC} 1+0.0125 \mathrm{M} \mathrm{H}_{2} \mathrm{SO}_{4}\right)$. From the extracted solution phosphorus was determined by colorimeter and $\mathrm{K}$ by flame photometer. $\mathrm{Ca}, \mathrm{Mg}$, and $\mathrm{Al}$ were extracted with $1 \mathrm{M} \mathrm{KC} 1$. Aluminum was determined by titration with $\mathrm{NaOH}$ and $\mathrm{Ca}$ and $\mathrm{Mg}$ by titration with EDTA from the extracted solution. Micronutrients were determined on a portion of the extract for $\mathrm{P}$ by atomic absorption spectrophotometry (Embrapa, 1997).

The research was conducted in an area that had been cultivated in NTS for six years $(2001 / 2002$ - 2006/2007) in rotations with corn (2001, 2003 and 2005) and soybean (2002, 2004 and 2006) in the raining season, and fallow in the dry season.

This was a three-year study with cover crop-rice or soybean-cover crop-rice rotations. Crops were sown in November 2007 (cover crops), November 2008 (upland rice or soybean), March 2009 (cover crops again), and November 2009 (only upland rice again). In the second year (November 2008), sownhalf of each cover crop strip was sown with soybean and the other half of each cover crop strip with upland rice. After the harvesting of these crops (March of 2009), sownall cover crops were sown again. In the third year (November 2009), sownupland rice was sown on all cover crops strips. This experiment was conducted to assess this upland rice crop growing under cover crops with previous summer crop of rice or soybean.

Table 1 - Soil chemical properties at the experimental area

\begin{tabular}{|c|c|c|c|c|c|c|c|c|c|c|c|}
\hline Depth & $\mathrm{pH}$ & $\mathrm{Ca}$ & $\mathrm{Mg}$ & $\mathrm{Al}$ & $\mathrm{P}$ & $\mathrm{K}$ & $\mathrm{Cu}$ & $\mathrm{Zn}$ & $\mathrm{Fe}$ & $\mathrm{Mn}$ & M.O. \\
\hline$(\mathrm{cm})$ & $\left(\mathrm{H}_{2} \mathrm{O}\right)$ & \multicolumn{3}{|c|}{$\left(\mathrm{cmol}_{\mathrm{c}} \mathrm{dm}^{-3}\right)$} & \multicolumn{6}{|c|}{$\left(\mathrm{mg} \mathrm{dm}^{-3}\right)$} & $\left(\mathrm{g} \mathrm{dm}^{-3}\right)$ \\
\hline \multicolumn{12}{|c|}{ October 2008} \\
\hline $0-5$ & 6.6 & 2.5 & 1.0 & 0.0 & 12.1 & 194.4 & 1.6 & 3.9 & 29.4 & 20.8 & 21.1 \\
\hline $5-10$ & 6.2 & 1.9 & 0.7 & 0.0 & 14.3 & 107.7 & 1.6 & 3.6 & 30.2 & 18.8 & 20.1 \\
\hline $10-20$ & 5.9 & 1.6 & 0.5 & 0.1 & 11.2 & 69.5 & 1.7 & 3.5 & 29.5 & 17.7 & 19.3 \\
\hline \multicolumn{12}{|c|}{ October 2009} \\
\hline $0-5$ & 5.7 & 2.8 & 1.4 & 0.0 & 14.6 & 191.9 & 1.5 & 4.9 & 30.6 & 25.2 & 23.0 \\
\hline $5-10$ & 5.7 & 2.1 & 0.8 & 0.0 & 15.4 & 144.9 & 1.8 & 4.4 & 32.2 & 20.9 & 17.5 \\
\hline $10-20$ & 5.5 & 1.8 & 0.5 & 0.1 & 15.9 & 107.7 & 1.9 & 4.0 & 32.3 & 18.4 & 13.5 \\
\hline
\end{tabular}


The cover crops used were: 1) Fallow (spontaneous vegetation, predominantly Bidens pilosa, Commelina benghalensis, Conyza bonariensis and Cenchrus echinatus), 2) Panicum maximum, 3) Brachiaria ruziziensis, 4) Brachiaria brizantha - cultivar Marandu, and 5) millet, Pennisetum glaucum - cultivar BN-2. Two additional treatments (control) were included with 6) fallow plus CTS (CTS, one plowing and two disking), and 7) - Brachiaria brizantha plus CTS.

The experimental design was a randomized block with three replications in a split-split plot arrangement split-split plot. In plots with $30 \times 40 \mathrm{~m}$, there were previous summer crops (rice or soybean); in split-plots with $6 \times 40 \mathrm{~m}$, five cover crops; and in the splitsplit plot with $6 \times 10 \mathrm{~m}$, four desiccation timing (30,20, 10 and 0 days before rice sowing). In addition, two treatments were included for the conventional tillage system (CTS, one disking and two plowing) consisting of upland rice sowing after soil incorporation of $B$. brizntha and fallow 30 days before.

At every stage of desiccation, glyphosate herbicide was applied at $1.8 \mathrm{~kg} \mathrm{ha}^{-1}$ acid equivalent (a.e.) using boom sprayer with spray volume of $200 \mathrm{~L} \mathrm{ha}^{-1}$. Environmental conditions during pulverization were weak winds, temperature around $25^{\circ} \mathrm{C}$ and relative humidity around $80 \%$. This operation was carried out after cover crop leaf drying of dew.

Tropical forages were sown when intercropped with corn (cultivar BRS 1010) in $0.20 \mathrm{~m}$ rows using a mechanical seed drill adjusted to distribute $10 \mathrm{~kg}$ seeds ha ${ }^{-1}$ with at least $30 \%$ of viable germination seeds, mixed with fertilizer (NPK formula 4-30-16, $400 \mathrm{~kg} \mathrm{ha}^{-1}$ ) at $10 \mathrm{~cm}$ deep, using the methodology recommended by Crusciol et al. (2010) in November/2007 and March/2009 (in this month cover crops were sown alone with no fertilizer). Millet was sown in March/2008 and March/ 2009, at spacing of $0.20 \mathrm{~m}$, cultural practices were conducted in accordance with Crusciol et al. (2010).

Soybean was sown in November of 2008 , using the cultivar 316 Emgopa RR in $0.45 \mathrm{~m}$ with 20 viable seeds per meter. We used $400 \mathrm{~kg} \mathrm{ha}^{-1}$ of NPK formula 00-20-20 and other cultural practices were performed in accordance with appropriate recommendations for that culture.

The cultivar of upland rice BRS Sertaneja was used, sown in November 2008 and November 2009, it was spaced at $0.35 \mathrm{~m}$, with a population of 60 plants per meter, using as fertilization $400 \mathrm{~kg} \mathrm{ha}^{-1}$ of NPK formula 05-30-15 and $60 \mathrm{~kg} \mathrm{ha}^{-1}$ of $\mathrm{N}$ one day after upland rice sowing. Culture management was performed according to the needs of the culture.

Plants of fallow, $P$. maximum, B. brizhanta, B. ruziziensis and millet were sampled from a $1.0 \mathrm{~m} \times 1.0 \mathrm{~m}$ area randomly selected in each split-split plot. The collected plant material was placed in paper bags and dried in a forced ventilation oven at $65^{\circ} \mathrm{C}$ and weighed. Cover crop dry matter was converted to ton per hectare.

Before harvesting, panicle number was recorded within one $\mathrm{m}$ of row in each splitsplit plot and the panicle number per square meter was sequentially computed. After that, randomly chosen panicles in each plot were used to count the number of spikelets per panicle, with a mean of 20 panicles.

Panicles were hand-threshed and the filled spikelets were manually separated using a sieve and then fertile splikelets (\%) were calculated. Grain (filled spikelets), after ovendrying at $60{ }^{\circ} \mathrm{C}$ until constant weight, was separated from the panicles and 1000-grain weight was measured. Grain yield $\left(\mathrm{kg} \mathrm{ha}^{-1}\right)$ was determined from rice plants manually harvested in three central rows of five meters in each plot. Plants were threshed and grain dried until the moisture content of seed reached $13 \%$.

Data were subjected to analysis of variance using the SAS program (SAS, 1999). The comparison of means was made using Tukey's test at $\mathrm{p}<0.05$. Pearson's correlation was used for cover crop dry matter on the soil surface at the desiccation-timing day, rice yield and its components at $\mathrm{p}<0.05$.

\section{RESULTS AND DISCUSSION}

The triple interaction among previous summer crop (rice or soybean), cover crops and 
desiccation timing was significant only for cover crop dry matter production (Table 2). Therefore, cover crop dry matter yields were different when soybean or upland rice was the previous crop (Figure 1). When desiccation was made at the day of upland rice sowing, except for $B$. brizantha, rice/cover crops rotation provided lower dry matter yield for all cover

Table 2 - Summary of variance analysis for cover crop dry matter and upland rice grain yield

\begin{tabular}{|l|c|c|c|}
\hline \multicolumn{1}{|c|}{ Source of variation } & Degree of freedom & $\begin{array}{c}\text { f value for cover crops } \\
\text { dry matter }\end{array}$ & f value for rice yield \\
\hline Cover crop (CC) & 4 & $<.001$ & $<.001$ \\
\hline Previous summer crop (PSC) & 1 & 0.006 & $<.001$ \\
\hline Desiccation timing (DT) & 3 & 0.483 & 0.049 \\
\hline Replications & 2 & $<.001$ & 0.102 \\
\hline CC*PSC & 4 & 0.014 & 0.002 \\
\hline CC $*$ DT & 12 & 0.175 & 0.998 \\
\hline PSC*DT & 3 & 0.884 & 0.605 \\
\hline CC*PSC*DT & 12 & 0.006 & 0.937 \\
\hline
\end{tabular}

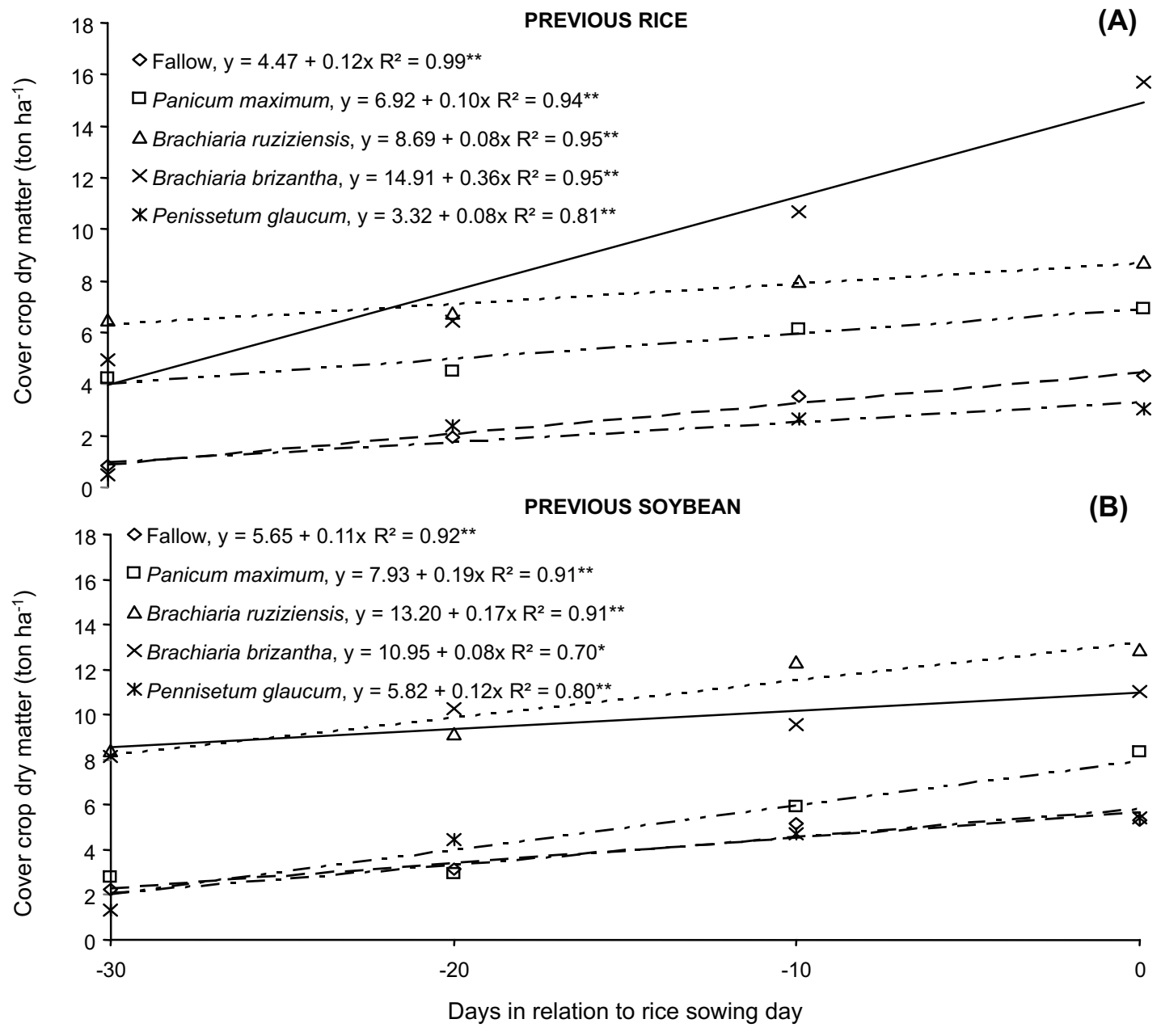

Figure 1 - Cover crop dry matter (ton ha ${ }^{-1}$ ) as a function of days before upland rice sowing and previous summer crop upland rice (A) or soybean (B) in no-tillage system. Santo Antônio de Goiás, GO, Brazil. 
crops than soybean/ or cover crops. This can have occurred because soybean can add more nitrogen to the soil compared to rice. According to Dabney et al. (2001) and Filizadeh et al. (2007), legumes contribute with nitrogen to subsequent crops or cover crops.

Regardless of which was the previous crop, the dry matter yield of cover crops increased as desiccation was made closer to the rice sowing (Figure 1) date. When rain starts (October/November) cover crops roots are still functional and high temperatures provide good conditions for the regrowing of these cover crops (Pacheco et al., 2011). Thus, the longer period of time to grow cover crops resulted in higher dry matter production.

In general, fallow and millet produced the lowest amount of dry matter in both previous crops (Figure 1). That probably happened because they are not perennial plants. After they finish their vital cycle, they spread their seeds to the soil. When the rainy season starts (September), they grow from the seeds in the soil and do not have enough time (only two months) to accumulate dry matter (November) (Pacheco et al., 2011). On the other hand, $B$. ruziziensis, $B$. brizantha and $P$. maximum are perennial plants and produced the highest amounts of dry matter. For this reason, these cover crops are very important for the Cerrado region, where the soil has low cation exchange and water storage potential, with widespread deficiency of nutrients, particularly phosphorus (Oliveira Junior, 2011), and the straw degradation from these cover crops can help increase nutrients in the soil.

Regarding upland rice yield, statistical analysis showed significance for desiccation timing and for the interaction between cover crops and previous crops by $\mathrm{p}<0.05$ (Table 2). Therefore, it can be noted that higher rice yield was obtained with larger interval between cover crop desiccation and rice sowing (Figure 2). Also, during this study it was possible to observe that desiccation made within 10 or more days before rice sowing allowed a greater performance of the planter machine, once green cover crops are not easy to cut using planter machine, and that reduces the efficiency of the sowing operation (Grego
\& Benez, 2003). Short intervals between desiccation and crop sowing in areas with large amount of biomass can damage the crops (Constantin et al., 2009). Besides the issues with the sowing process, it can also physically hinder the emergence of plants, as well as provide shading in the initial period, reducing the subsequent vegetative growth that can cause negative effects on productivity (Constantin et al., 2008; Nascente et al., 2012), just as how it happened to rice specially on Brachiaria brizantha and Brachiaria ruziziensis under NTS (Table 3).

Soybean/millet and soybean/fallow under no-tillage and soybean/ incorporated fallow have provided the best upland rice yields (Table 3). It was possible to observe that even having been cultivated one year before, soybean allowed for a better rice yield compared to previous upland rice for all kinds of cover crops, in tillage and no-tillage systems. In average, previous upland rice had yielded $2,287 \mathrm{~kg} \mathrm{ha}^{-1}$ and previous soybean $3,469 \mathrm{~kg} \mathrm{ha}^{-1}$, differing from each other at $\mathrm{p}<0.05$ (Table 3). According to Guimarães \& Stone (2003), upland rice had higher yields when cultivated after soybean compared to grasses, they attributed it to increased nitrogen availability in this environment. Also, Filizadeh et al. (2007) had 20\% more yield, with previous soybean instead of previous rice. According to the data, to achieve high rice yield, a good option is to use soybean as previous summer crop.

Regarding the different cover crops, millet on both previous crops, and fallow, especially on previous soybean, favored better upland rice yield (Table 3). Additionally, Menezes et al. (2001), Pacheco et al. (2011) and Moro (2011)

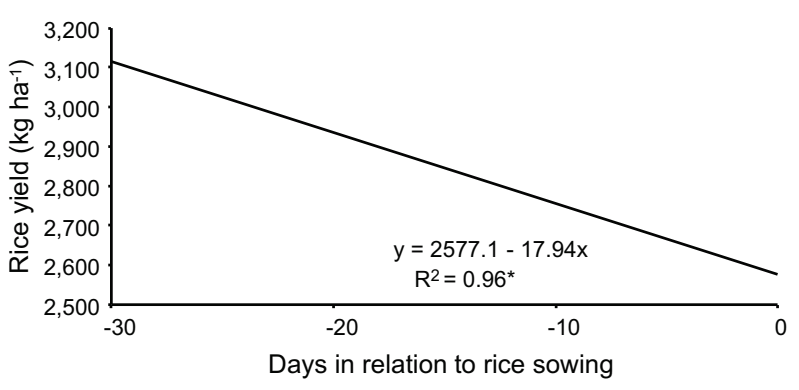

Figure 2 - Upland rice yield $\left(\mathrm{kg} \mathrm{ha}^{-1}\right)$ affected by desiccation timing before rice sowing. 
Table 3 - Upland rice yield and its components under cover crops and tillage systems with soybean or upland rice as previous summer crops

\begin{tabular}{|c|c|c|c|c|c|c|c|c|c|c|}
\hline \multirow{3}{*}{ Cover crops } & \multicolumn{2}{|c|}{ Panicles $\mathrm{m}^{-2}$} & \multicolumn{2}{|c|}{ Spikelets per panicle } & \multicolumn{2}{|c|}{ Spikelets fertility (\%) } & \multicolumn{2}{|c|}{ 1000-grain weight $(\mathrm{g})$} & \multicolumn{2}{|c|}{ Grain yield $\left(\mathrm{kg} \mathrm{ha}^{-1}\right)$} \\
\hline & \multicolumn{10}{|c|}{ Previous crops } \\
\hline & Rice & Soybean & Rice & Soybean & Rice & Soybean & Rice & Soybean & Rice & Soybean \\
\hline Fallow & 68 a A & 99 a A & $179 \mathrm{ab} A$ & $181 \mathrm{aA}$ & $66.6 \mathrm{~b} \mathrm{~B}$ & 80.3 a A & $27.8 \mathrm{ab} \mathrm{B} *$ & $36.5 \mathrm{ab} A$ & $2,159 \mathrm{abc} \mathrm{B}$ & 4,507 a A \\
\hline Panicum maximum & 83 a A & 65 a A & $167 \mathrm{~b} \mathrm{~B}$ & 184 a A & $75.0 \mathrm{ab} \mathrm{A}$ & $76.4 \mathrm{a} \mathrm{A}$ & $27.6 \mathrm{ab} \mathrm{B}$ & $34.1 \mathrm{ab} \mathrm{A}$ & $2,633 \mathrm{ab} \mathrm{B}$ & $3,088 \mathrm{bc} \mathrm{A}$ \\
\hline Brachiaria ruziziensis & 62 a A & 63 a A & $162 \mathrm{~b} \mathrm{~A}$ & 172 a A & $70.2 \mathrm{~b} \mathrm{~B}$ & $75.2 \mathrm{aA}$ & $26.7 \mathrm{~b} \mathrm{~A}$ & $29.7 \mathrm{~b} \mathrm{~A}$ & $1,595 \mathrm{c} \mathrm{B}$ & $2,240 \mathrm{c} \mathrm{A}$ \\
\hline Brachiaria brizantha & 56 a $\mathrm{A}$ & 58 a A & $173 \mathrm{~b} \mathrm{~A}$ & 195 a A & $73.1 \mathrm{ab} \mathrm{A}$ & 75.7 a A & $28.2 \mathrm{ab} \mathrm{B}$ & $34.8 \mathrm{ab} \mathrm{A}$ & 1,772 bc B & $2,604 \mathrm{c} \mathrm{A}$ \\
\hline Penissetum glaucum & 58 a B & 98 a A & 222 a A & 199 a B & $72.7 \mathrm{ab} \mathrm{A}$ & 75.9 a A & $34.2 \mathrm{ab} \mathrm{A}$ & $33.7 \mathrm{ab} \mathrm{A}$ & 3,100 a B & 4,765 a A \\
\hline Fallow plowed & 54 a A & 78 a A & $204 \mathrm{ab} \mathrm{A}$ & 199 a B & $88.3 \mathrm{a} \mathrm{A}$ & 79.0 a A & 36.0 a A & 37.0 a A & 3,120 a B & $4,427 \mathrm{ab} \mathrm{A}$ \\
\hline B. brizantha plowed & 53 a A & 61 a A & $177 \mathrm{ab} \mathrm{A}$ & 185 a A & $76.0 \mathrm{ab} \mathrm{A}$ & $77.0 \mathrm{a} \mathrm{A}$ & $31.0 \mathrm{ab} \mathrm{A}$ & $36.0 \mathrm{ab} \mathrm{A}$ & 2,150 abc B & $3,081 \mathrm{bc} \mathrm{A}$ \\
\hline Average & $64 \mathrm{~B}$ & $76 \mathrm{~A}$ & $181 \mathrm{~A}$ & $186 \mathrm{~A}$ & $72 \mathrm{~B}$ & $76.8 \mathrm{~A}$ & $29.3 \mathrm{~B}$ & $34.0 \mathrm{~A}$ & $2,287 \mathrm{~B}$ & $3,469 \mathrm{~A}$ \\
\hline \multicolumn{11}{|l|}{ Tillage systems } \\
\hline No-tillage & $65 \mathrm{a}$ & $77 \mathrm{a}$ & $180 \mathrm{a}$ & $186 \mathrm{a}$ & $72,0 \mathrm{~b}$ & $77,0 \mathrm{a}$ & $28.9 \mathrm{a}$ & $33.8 \mathrm{a}$ & $2,635 \mathrm{a} \mathrm{B}$ & 3,754 a A \\
\hline Conventional tillage & $53 \mathrm{a}$ & $70 \mathrm{a}$ & $190 \mathrm{a}$ & $192 \mathrm{a}$ & $78,0 \mathrm{a}$ & $78,0 \mathrm{a}$ & $33.5 \mathrm{a}$ & $36.5 \mathrm{a}$ & 2,252 a B & 3,441 a A \\
\hline $\mathrm{CV}(\%)$ & 41.9 & 47.7 & 14.8 & 13.7 & 7.7 & 6.9 & 21.8 & 15.2 & 8.9 & 7.8 \\
\hline
\end{tabular}

* Same lowercase letter vertical or uppercase horizontal do not differ by Tukey's test at $\mathrm{p}<0.05$.

have found better rice yield with millet as a cover crop. The authors believe these results are due to the fact that millet at the time of upland rice sowing was already in an advanced state of decomposition, which decreased the possibility of the presence of allelopathic substances released after desiccation that could have reduced the amount of nutrients, especially nitrogen, in connection with plant debris and soil microbial population (Souza et al., 2006).

The high rice grain yield on fallow straw may be due to the fact that rice is a crop that has slow initial growth and that shows great sensitivity to competition with other plants (Menezes et al., 2001; Fageria et al., 2011). Thus, the proper management of plants (weeds) and the desiccation process have favored the full development of culture without competition. However, the use of fallow is not a good option, because it can increase the number of weeds in agriculture areas (Nascente \& Crusciol, 2012).

On the other hand, cover crops like $B$. brizantha and $B$. ruziziensis provided the worst rice yields, maybe because they are more difficult to control. Constantin et al. (2009), Nunes et al. (2009), Pacheco et al. (2011), Nascente \& Crusciol (2012) and Nascente et al. (2012) have reported difficult control of Panicum and Brachiaria species with glyphosate. In addition to that, these cover crops may have some allelopathic effects that hamper the development of rice plants. Souza et al. (2006) reported allelopathic effects caused by the species Brachiaria, that can reduce crop seed germination, plant development and grain yield; similarly to what has occurred in this trial with Brachiaria ruziziensis and Brachiaria brizantha as cover crops.

Fischer et al. (1995, 2001), Nunes et al. (2009) and Crusciol et al. (2010) have added that Brachiaria spp. and Panicum spp. produce a large amount of biomass that may damage the emergence and establishment of rice plants. Agreeing with this information, it has been found by statistical analysis that the correlation among cover crop dry matter, upland rice grain and its components were significant for panicle $\mathrm{m}^{2}$, spikelets per panicle, 1000-grain weight and grain yield (Table 4).

Some authors did not have good rice yield at no-tillage system in comparison to conventional tillage system, and reported that it is necessary to develop techniques that will allow this crop to grow under NTS. However, rice after soybean/millet and after soybean/ fallow in NTS was observed to have had the highest grain yields and they were similar to the fallow treatment in conventional tillage system (Table 3). Moura Neto et al. (2002), Reis et al. (2008) and Nascente et al. (2011) 
Table 4 - Linear correlation coefficient (r) and probability value ( $p$ ) among cover crop dry matter and rice grain yield and its components, in treatments with cover crops in no-tillage system

\begin{tabular}{|c|c|c|c|c|c|c|}
\hline Variables & & Panicle $\mathrm{m}^{-2}$ & $\begin{array}{c}\text { Spikelets per } \\
\text { panicle }\end{array}$ & $\begin{array}{c}\text { Spikelets } \\
\text { fertility }\end{array}$ & $\begin{array}{c}\text { 1.000-grain } \\
\text { weight }\end{array}$ & Grain yield \\
\hline \multirow{2}{*}{ Cover crop dry matter } & $\mathrm{r}$ & -0.2073 & -0.1956 & -0.0098 & -0.1645 & -0.4168 \\
\cline { 2 - 7 } & $p$ & 0.0231 & 0.0323 & 0.9155 & 0.0727 & 0.0001 \\
\hline
\end{tabular}

also found similar results with no difference between conventional tillage and no-tillage systems. Moreover, it was very clear that using soybean as a previous summer crop was much better than using previous upland rice at no-tillage and conventional tillage systems (Table 3).

Regarding the upland rice yield components, it is important to note that when the precedent summer crop was soybean only the 1000-grain weight was significantly affected by cover crops (Table 3). The tillage of fallow plot provided higher grain weight than $B$. ruziziensis considering both precedent summer crops. When the precedent summer crop was upland rice, millet provided a greater number of spikelets per panicle than B. ruziziensis, B. brizantha and Panicum maximum at $\mathrm{p}<0.05$. The fertile spikelet percentage was lowest for treatments under fallow and Brachiaria ruziziensis and differed from incorporated fallow. In average, soybean as previous summer crop provided higher number of panicle $\mathrm{m}^{-2}$, fertile spikelet percentage and 1.000-grains weight, explained the higher upland rice grain yield. Tillage systems differed only in relation to fertile spikelet percentage, which was higher under conventional tillage system.

To conclude, it was observed that time period of cover crop desiccation affects significantly upland rice grain yield and it is higher when chemical management in the cover crops is made farther from the rice sowing day (from 2,577.1 $\mathrm{kg} \mathrm{ha}^{-1}$, desiccation made at rice sowing, to $3,115.30 \mathrm{~kg} \mathrm{ha}^{-1}$, desiccation made 30 days before rice sowing). In addition, upland rice grain yield and its components under cover crops are significantly affected by cover crops, where millet and fallow provide better yield instead of the other cover crops. Soybean as a previous summer crop allows better upland rice yield $\left(3,754 \mathrm{~kg} \mathrm{ha}^{-1}\right)$ rather than upland rice as a previous summer crop $\left(2,635 \mathrm{~kg} \mathrm{ha}^{-1}\right)$. Soybean/fallow $\left(4,507 \mathrm{~kg} \mathrm{ha}^{-1}\right)$ and soybean/ millet $\left(4,765 \mathrm{~kg} \mathrm{ha}^{-1}\right)$ rotations at no-tillage system and soybean/incorporated fallow $\left(4,427 \mathrm{~kg} \mathrm{ha}^{-1}\right)$ at conventional tillage system provide the highest upland rice yields. Upland rice grain yield is similar in no-till $\left(3,194 \mathrm{~kg} \mathrm{ha}^{-1}\right)$ and conventional till systems $\left(2,878 \mathrm{~kg} \mathrm{ha}^{-1}\right)$.

\section{ACKNOWLEDGMENTS}

We thank EMBRAPA, for supporting this research and for providing $\mathrm{PhD}$. scholarship to the first author; and to CNPq, for providing scholarships to the second and third authors.

\section{LITRATURE CITED}

COMPANHIA NACIONAL DE ABASTECIMENTO CONAB. $4^{\circ}$ Levantamento da produção de grãos - safra 2010/11. Disponível em:<www.conab.gov.br> Acesso em: 5 fev. 2012

CONSTANTIN, J. et al. Sistemas de manejo de plantas daninhas no desenvolvimento e na produtividade da soja. Bragantia, v. 68, n. 1, p. 125-135, 2009

CONSTANTIN, J. et al. Influência do glyphosate na dessecação de capim-braquiária e sobre o desenvolvimento inicial da cultura do milho. Planta Daninha, v. 26, n. 3, p. $627-636,2008$.

COUPLAND, D.; LUTMAN, P. Investigations into the movement of glyphosate from treated to adjacent untreated plants. An. Appl. Biol., v. 101, n. 2, p. 315-321, 1982.

CRUSCIOL, C. A. C. et al. Benefits of integrating crops and tropical pastures as systems of production. Better Crops, v. 94, n. 2 , p. 14-16, 2010. 
DABNEY, S. M.; DELGADO, J. A.; REEVES, D. W. Use of winter cover crops to improve soil and water quality. Comm. Soil Sci. Plant Anal., v. 7, n. 7, p. 1221-1250, 2001

\section{EMPRESA BRASILEIRA DE PESQUISA}

AGROPECUÁRIA - EMBRAPA. Centro Nacional de Pesquisa de solos. Manual de métodos de análise de solo 2. ed. Rio de Janeiro: Embrapa Solos, 1997. 212 p.

\section{EMPRESA BRASILEIRA DE PESQUISA} AGROPECUÁRIA - EMBRAPA. Sistema brasileiro de classificação de solos. Brasília: Embrapa Produção de Informação/Rio de Janeiro: Embrapa Solos, 2006. 306 p.

FAGERIA, N. K.; MORAES, O.; VASCONCELOS, M. J Yield and yield components of upland rice as influenced by nitrogen sources. J. Plant Nut., v. 34, n. 1, p. 361-370, 2011.

FISCHER, A. J. et al. Components of early competition between upland rice (Oryza sativa L.) and Brachiaria brizantha (Hochst. ex A.Rich) Stapf. Int. J. Pest Manag., v. 41, n. 2, p. 100-103, 1995.

FISCHER, A. J. et al. Competitiveness of semidwarf upland rice cultivars against palisadegrass (Brachiaria brizantha) and signalgrass (B. decumbens). Agron. J., v. 93, p. 967-73, 2001.

FILIZADEH, Y; REZAZADEH, A.; YOUNESSI, Z. Effects of crop rotation and tillage depth on weed competition and yield of rice in the paddy fields of Northern Iran. J. Agri. Sci. Technol., v. 10, n. 9, p. 99-105, 2007.

GREGO, C. R.; BENEZ, S.H. Manejo da cobertura vegetal do solo na implantação da cultura da soja (Glycine Max (L.) Merril) semeada com dois mecanismos sulcadores. Energ. Agric., v. 18, n. 3, p. 48-52, 2003.

GUIMARÃES, C. M.; STONE, L.F. Adubação nitrogenada do arroz de terras altas no Sistema Plantio Direto. R. Bras. Energ. Agric. Amb., v. 7, n. 2, p. 210-214, 2003.

MAHMOUDI, M. et al. Residual effect of thiobencarb and oxadiargyl on spinach and lettuce in rotation with rice.

J. Agri. Sci. Technol., v. 13, n. 5, p. 785-794, 2011.

MENEZES, V.G. et al. Semeadura direta de arroz em sucessão a espécies de cobertura de inverno. Pesq. Agropec. Bras., v. 36, n. 9 , p. 1107-1115, 2001.

MORO, E. Formas de nitrogênio no solo e produção do arroz de terras altas em plantio direto. 2011. $120 \mathrm{f}$. Tese (Doutorado em Agronomia) - Universidade Estadual Paulista, Botucatu, 2011.
MOURA NETO, F. P.; SOARES, A. A.; AIDAR, H. Desempenho de cultivares de arroz de terras altas sob plantio direto e convencional. Ci. Agrotec., v. 26, n. 5, p. 904-910, 2002 .

NASCENTE, A. S. et al. Produtividade do arroz de terras altas em função do manejo do solo e da época de aplicação de nitrogênio. Pesq. Agropec. Trop., v. 41, n. 1, p. 60-65, 2011.

NASCENTE, A. S.; CRUSCIOL, C. A. C. Cover crops and herbicide timing management on soybean yield under no-tillage system. Pesq. Agropec. Bras., v. 47, n. 2, p. 187-192, 2012.

NASCENTE, A.S. et al. Brachiaria ruziziensis and herbicide on yield of upland rice. Planta Daninha, v. 30, n. 4, p. 729$735,2012$.

NUNES, A. S. et al. Épocas de manejo químico de Brachiaria decumbens antecedendo o plantio direto de soja

Planta Daninha, v. 27, n. 2, p. 297-302, 2009.

OLIVEIRA JUNIOR, A.; PROCHNOW, L. I.; KLEPKER, D. Soybean yield in response to application of phosphate rock associated with triple superphosphate. Sci. Agric., v. 68 , n. 3, p. 376-385, 2011.

PACHECO, L. P. et al. Produção de fitomassa e acúmulo e liberação de nutrientes por plantas de cobertura na safrinha. Pesq. Agropec. Bras., v. 46, n. 1, p. 17-25, 2011.

REIS, M. S. et al. Desempenho de cultivares e linhagens de arroz de terras altas sob plantio direto e convencional. $\mathbf{C i}$. Agrotec., v. 32, n. 5, p. 1435-1440, 2008.

SAS Institute. Procedure guide for personal computers Version 5. Cary: 1999.

SILVA, A. C. et al. Micorrização e épocas de dessecação de Brachiaria brizantha no desenvolvimento da soja

Planta Daninha, v. 24, n. 2, p. 271-277, 2006.

SOUZA, L. S. et al. Efeito alelopático de capim-braquiária (Brachiaria decumbens) sobre o crescimento inicial de sete espécies de plantas cultivadas. Planta Daninha, v. 24, n. 4, p. 657-668, 2006.

TIMOSSI, P. C.; DURIGAN, J. C.; LEITE, G. J. Formação de palhada por braquiárias para adoção do sistema plantio direto. Bragantia, v. 66, n. 4, p. 617-622, 2007

YAHUZA, I. Review of some methods of calculating intercrop efficiencies with particular reference to the estimates of intercrop benefits in wheat/faba bean system. Int. J. BioSci. Technol., v. 1, n. 5, p. 18-30, 2011. 